ORNL/RASA-97/2

\title{
Radiological Survey Results for the Niagara Mohawk Right-of-Way, Tonawanda, New York (TNY004)
}

S. P. McKenzie

M. S. Uziel

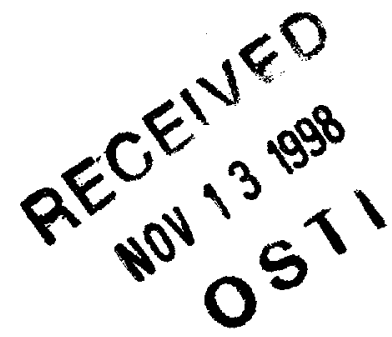

WMUAGED ANO OPERATED BY

LOCKHEED WARTIN ENERGY RESEARCH CORPORATION FOA THE UNTEO STATES

DEPARTMENT OF ENERGY 
This report has been reproduced directly from the best available copy.

Available to DOE and DOE contractors from the Office of Scientific and Technical Information, P.O. Box 62, Oak Ridge, TN 37831; prices available from 423-576-8401.

Available to the public from the National Technical Information Service, U.S. Department of Commerce, 5285 Port Royal Rd., Springfield, VA 22161.

This report was prepared as an account of work sponsored by an agency of the United States Government. Neither the United States Government nor any agency thereof, nor any of their employees, makes any warranty, express or implied, or assumes any legal liability or responsibility for the accuracy, completeness, or usefulness of any information, apparatus, product, or process disclosed, or respresents that its use would not infringe privately owned rights. Reference herein to any specific commercial product, process, or sevice by trade name, trademark, manufacturer, or otherwise, does not necessarily constitute or imply its endorsement, recommendation, or favoring by the United States Government or any agency thereot. The views and opinions of authors expressed herein do not necessarily state or reflect those of the United States Government or any agency thereof. 


\section{DISCLAIMER}

Portions of this document may be illegible in electronic image products. Images are produced from the best available original document. 
Prepared for the U.S. ARMY CORPS OF ENGINEERS, Buffalo District (Budget and Reporting Code 43WM1 1202; Agency Code DAG)

\title{
Radiological Survey Results for the Niagara Mohawk Right-of-Way, Tonawanda, New York (TNY004)
}

S. P. McKenzie and M. S. Uziel

Date Issued-November 1998

\author{
Investigation Team \\ R. D. Foley - Measurement Applications and Development Manager \\ M. E. Murray - FUSRAP Project Director \\ S. P. McKenzie - Survey Team Leader \\ Survey Team Members
J. P. Abston
D. E. Rice
R. C. Gosslee
D. A. Roberts
S. P. McKenzie
R. E. Rodriguez

Work performed by the

MEASUREMENT APPLICATIONS AND DEVELOPMENT GROUP LIFE SCIENCES DIVISION

\author{
Prepared by the \\ OAK RIDGE NATIONAL LABORATORY \\ Oak Ridge, Tennessee 37831-6285 \\ managed by \\ LOCKHEED MARTIN ENERGY RESEARCH CORP. \\ for the \\ U.S. DEPARTMENT OF ENERGY \\ under contract DE-AC05-960R22464
}




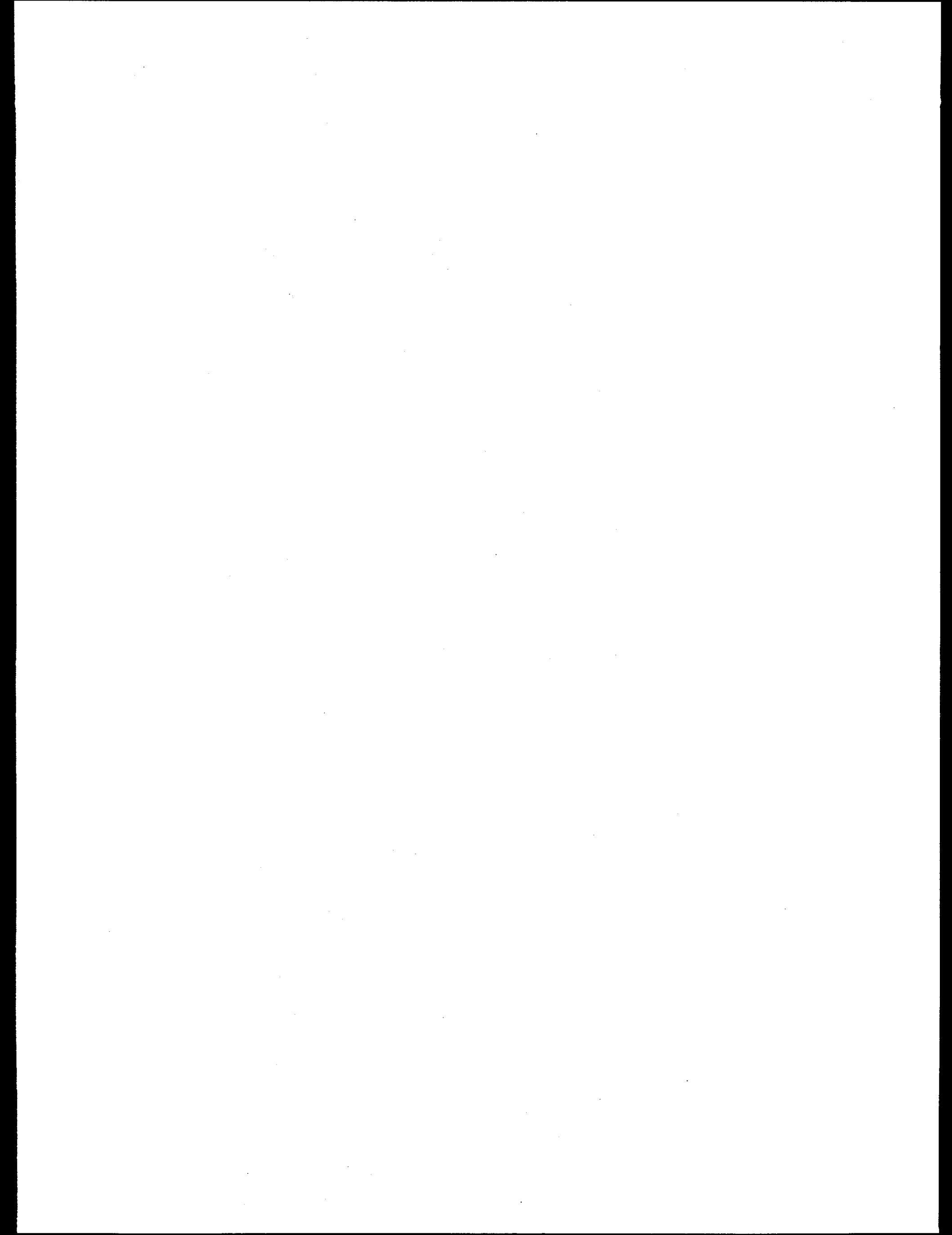




\section{CONTENTS}

LIST OF FIGURES $\ldots \ldots \ldots \ldots \ldots \ldots \ldots \ldots \ldots \ldots \ldots \ldots \ldots \ldots \ldots \ldots \ldots \ldots$

LIST OF TABLES $\ldots \ldots \ldots \ldots \ldots \ldots \ldots \ldots \ldots \ldots \ldots \ldots \ldots \ldots \ldots \ldots \ldots \ldots \ldots \ldots \ldots \ldots$

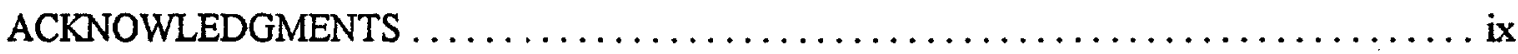

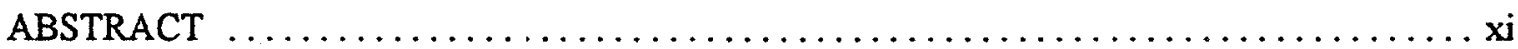

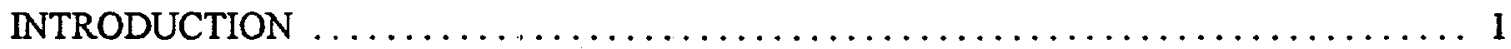

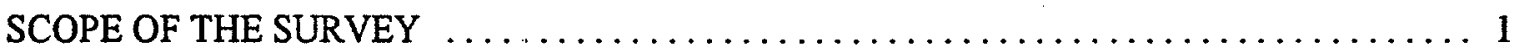

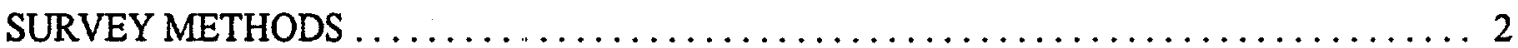

GAMMA RADIATION MEASUREMENTS $\ldots \ldots \ldots \ldots \ldots \ldots \ldots \ldots \ldots \ldots \ldots \ldots \ldots \ldots \ldots \ldots \ldots$

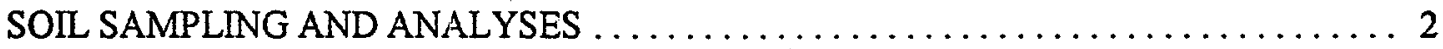

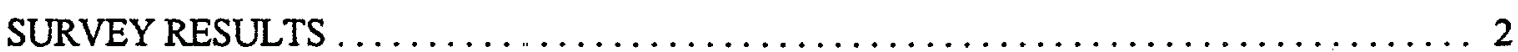

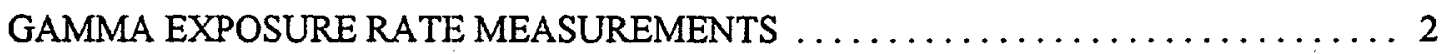

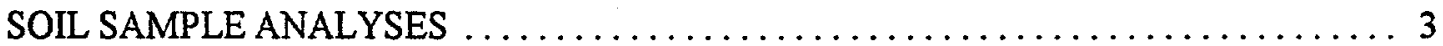

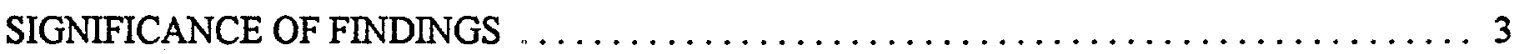

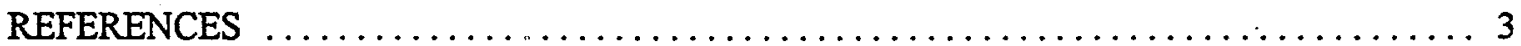




\section{LIST OF FIGURES}

1 Diagram showing general location of the Niagara Mohawk Power Corporation right-of-way in relation to the former Linde plant site in Tonawanda, New York

2 Diagram delineating portion of Niagara Mohawk right-of-way included in this survey

3 Diagram showing biased soil sampling locations on the Niagara Mohawk

Power Corporation right-of-way, Tonawanda, New York

4 Diagram showing surface and 1-m gamma exposure rates on the Niagara Mohawk Power Corporation right-of-way 



\section{LIST OF TABLES}

1 Applicable guidelines for protection against radiation $\ldots \ldots \ldots \ldots \ldots \ldots \ldots \ldots$

2 Background radiation levels and concentrations of selected radionuclides in soil near Tonawanda, New York . . . . . . . . . . . . . . . . . .

3 Concentrations of selected radionuclides in soil samples collected from the Niagara Mohawk Power Corporation right-of-way,

Tonawanda, New York 


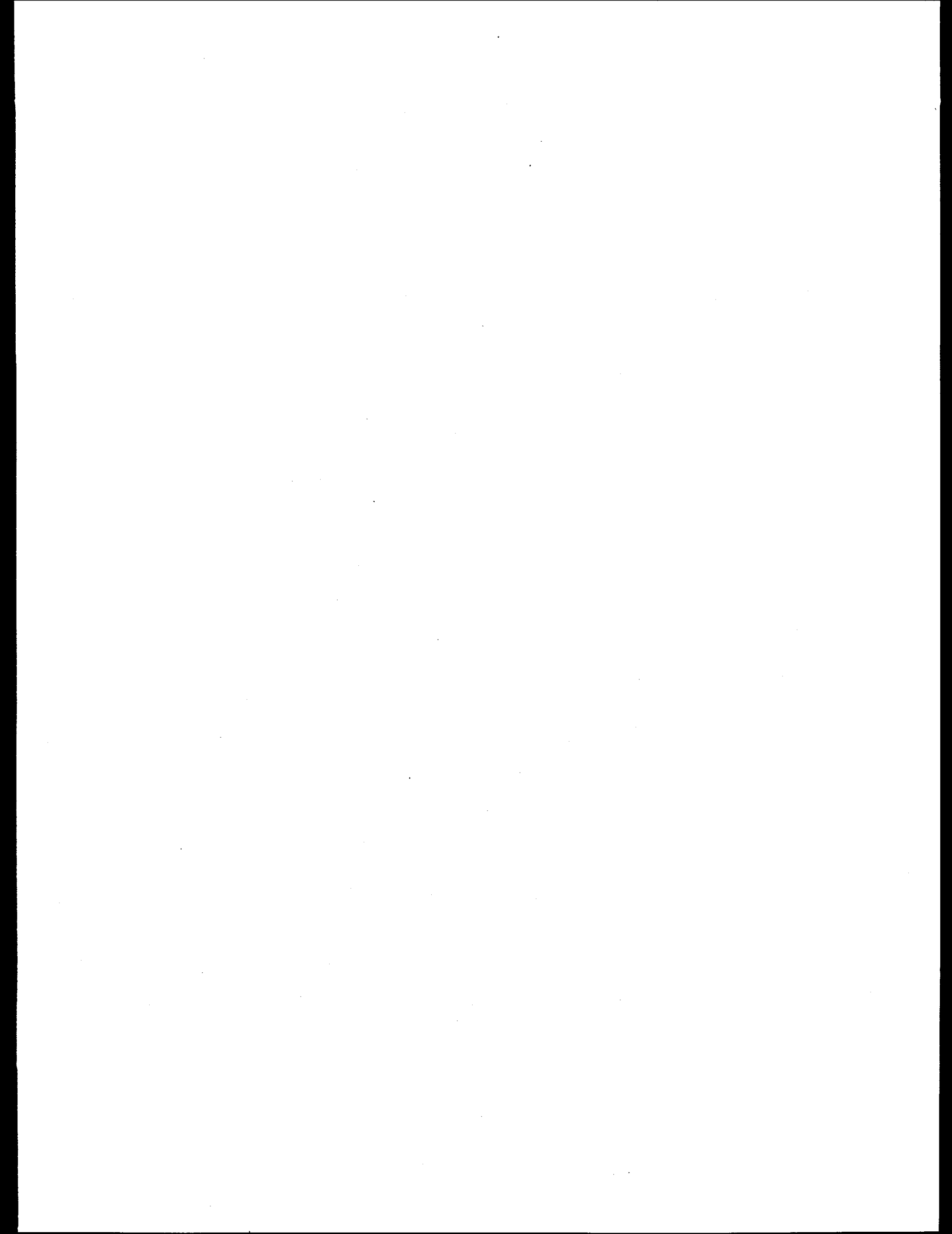




\section{ACKNOWLEDGMENTS}

The portion of this project completed after October 1, 1997, was sponsored by the U.S. Army Corps of Engineers, Buffalo District. Prior to that date, the project was sponsored by the Office of Environmental Restoration, U.S. Department of Energy, under contract DE-AC05-840R21400 with Martin Marietta Energy Systems, Inc., and DE-AC05-960R22464 with Lockheed Martin Energy Research Corp.

The authors wish to acknowledge the contributions of J. P. Abston, R. F. Carrier, R. L. Coleman, R. C. Gosslee, M. E. Murray, D. E. Rice, D. A. Roberts, R. E. Rodriguez, and J. K. Williams of the Measurement Applications and Development Group, Oak Ridge National Laboratory, for sample preparation and participation in the analyses, editing, and reporting of data for this survey. The authors also wish to thank James A. Miller and Carl A. Reisig of the Niagara Mohawk Power Corporation. 


\begin{abstract}
At the request of the U.S. Department of Energy (DOE), a team from Oak Ridge National Laboratory conducted a radiological survey of a small portion of the Niagara Mohawk Power Corporation right-of-way in Tonawanda, New York. The purpose of the survey was to determine if radioactive residuals had migrated from or been redistributed onto the Niagara Mohawk right-of-way from the former Linde property to the west. The Linde Air Products Division of Union Carbide Corporation, Tonawanda, New York, had used radioactive materials at that location for work performed under government contract from 1942 through 1948.

The survey was performed in May 1996 in response to Formerly Utilized Sites Remedial Action Program (FUSRAP) requirements. These requirements dictate that the radiological status of certain vicinity properties shall be assessed and documented according to prescribed procedures prior to certification of the property for release for unrestricted use. Such release can only be granted if the property is found to be within current applicable authorized limits.

The survey included a gamma scan of accessible areas and the collection and radionuclide analysis of soil samples from the portion of right-of-way located east of the former Linde plant site and north of the railway spur entrance gate. Results of the survey indicate that radioactive material probably originating from the Linde plant is located on the Niagara Mohawk right-of-way in the area surveyed. Surface gamma exposure rates were elevated above typical background levels. Four scattered surface soil samples exceeded DOE guideline values for ${ }^{238} U$, and 8 of 13 surface soil samples exceeded DOE guideline values for ${ }^{226} \mathrm{Ra}$. The radionuclide distribution in these samples was similar to that found in materials resulting from former processing activities at the Linde site. It is recommended that the property be designated for remedial action by DOE.
\end{abstract}




\section{Radiological Survey Results for the Niagara Mohawk Right-of-Way, Tonawanda, New York (TNY004)*}

\section{INTRODUCTION}

From 1942 through approximately 1948, the Linde Air Products Division of Union Carbide Corporation, Tonawanda, New York, was one of many companies performing work associated with the development of nuclear energy for defense-related projects. This work was conducted under government contract to the Manhattan Engineer District (MED) and the Atomic Energy Commission (AEC). During the first 3 years, pitchblende ore from the Belgian Congo and concentrates from the Colorado Plateau ore were converted to $\mathrm{U}_{3} \mathrm{O}_{8}$. A second process yielding $\mathrm{UO}_{2}$ was conducted for about a year, and a third process, converting $\mathrm{UO}_{2}$ to green salt $\left(\mathrm{UF}_{4}\right)$, operated during World War $\mathrm{II}$ and the following 2 years. Linde also developed and produced barrier material for the Oak Ridge Gaseous Diffusion Plant. Other contracts have been identified, but the exact nature of the work involved is unknown.'

As a result of these and similar activities, equipment, buildings, and land at some of the sites became radiologically contaminated resulting in low levels of contamination on the properties. At contract termination, sites used by contractors were decontaminated in accordance with the standards and survey methods in use at that time. Since the original assessments, radiological criteria and guidelines for the release of such sites for unresiricted use have become more stringent. In some instances, records documenting decontamination efforts cannot be found, and the final radiological conditions of the site cannot be adequately determined. As a result, the Formerly Utilized Sites Remedial Action Program (FUSRAP) was established in 1974 to identify these formerly used sites and to reevaluate their radiological status. ${ }^{1}$ The radiological assessment showing the presence of radioactive residuals at the Linde site was performed in $1978 .^{2}$

Occasionally, nearby private and commercial properties also became contaminated through migration or redistribution of the radioactive residuals from the original site. ${ }^{3}$ The radiological survey detailed in this report was performed under the FUSRAP program as a follow-up to earlier investigations and as a precaution to ensure that no residual radioactive materials exceeding current DOE guidelines were present on the Niagara Mohawk Power Corporation right-of-way. The purpose of the survey was to determine if any contamination may have been transferred from the Linde site or from the railroad, which was used for shipping contaminated material to and from the Linde site, onto the Niagara Mohawk right-of-way. The relative locations of the properties are diagramed on Fig. 1.

The Niagara Mohawk Power Corporation right-of-way lies adjacent to the eastern border of the former Linde plant occupying an area $\sim 30 \mathrm{ft}$ wide between the Linde fence and the ConRail railroad property (Fig. 1). The survey was limited to the northern quarter of the right-of-way (Fig. 2) that borders the Linde property. Most of the data presented in this report was obtained in May 1996.

\section{SCOPE OF THE SURVEY}

The radiological survey included (1) a surface gamma scan of accessible areas of the property, (2) measurement of 1-m gamma exposure rates at soil sampling locations, and (3) collection and radionuclide analysis of biased soil samples from locations with slightly elevated gamma levels.

\footnotetext{
*The survey was performed by members of the Measurement Applications and Development Group of the Life Sciences Division at Oak Ridge National Laboratory.
} 


\section{SURVEY METHODS}

A comprehensive description of the methods and instrumentation used in this survey and in the laboratory analyses is given in Procedures Manual for the ORNL Radiological Survey Activities (RASA) Program, ORNL/TM-8600 (April 1987) ${ }^{4}$ and Measurement Applications and Development Group Guidelines, ORNL-6782 (January 1995). ${ }^{5}$

Sampling and measurement locations were located by measuring the number of feet east of the Linde fence and the number of feet north of the mid-point of the gate on the railway spur entering the former Linde property (see Fig. 3).

\section{GAMMA RADIATION MEASUREMENTS}

Gamma radiation levels were determined using portable Nal gamma scintillation meters. Because $\mathrm{NaI}$ gamma scintillators are energy dependent, measurements of gamma radiation levels in counts per minute are normalized to pressurized ionization chamber (PIC) measurements to estimate gamma exposure rates in $\mu \mathrm{R} / \mathrm{h}$.

\section{SOIL SAMPLING AND ANALYSES}

The distribution of soil sampling locations was determined by accessibility because heavy brush and marshy, swampy conditions blocked access to much of the area. Systematic soil sampling could not be conducted. Surface and subsurface biased soil samples were collected at accessible locations to give a representation of rad levels at the site (Fig. 3). The highest concentration of soil samples was taken at the south end of the sampling area; fewer samples were collected as sampling operations were moved north.

\section{SURVEY RESULTS}

DOE guidelines are summarized in Table 1. Typical background radiation levels for the Tonawanda, New York, area are presented in Table 2. These data are provided for comparison with survey results presented in this section. All direct measurement results presented in this report are gross readings; background radiation levels have not been subtracted. Similarly, background concentrations have not been subtracted from radionuclide concentrations measured in soil samples.

\section{GAMMA EXPOSURE RATE MEASUREMENTS}

Scanning was very difficult or impossible because of low-lying swampy, marshy areas with standing water and heavy brush cover in some parts of the Niagara Mohawk right-of-way. Only $30 \%$ to $40 \%$ of the area was accessible.

The gamma scan of accessible areas revealed exposure rates ranging from 9 to $42 \mu \mathrm{R} / \mathrm{h}$ at the surface and 10 to $36 \mu \mathrm{R} / \mathrm{h}$ at $1 \mathrm{~m}$ (Fig. 4). Surface gamma exposure rates greater than typical background levels of $8-11 \mu \mathrm{R} / \mathrm{h}$ (Table 2) were observed at 11 of the 13 biased sampling locations. 


\section{SOIL SAMPLE ANALYSES}

The results of the soil sample analyses on 13 biased surface $(0-15 \mathrm{~cm})$ and subsurface $(15-30 \mathrm{~cm})$ soil samples are given in Table 3. Sample locations are shown on Fig. 3. Concentrations of ${ }^{238} \mathrm{U}$ ranged from 3.6 to $100 \mathrm{pCi} / \mathrm{g}$ in surface soil samples and 2.5 to $23 \mathrm{pCi} / \mathrm{g}$ in subsurface samples. Samples B5A, $\mathrm{B} 6 \mathrm{~A}, \mathrm{~B} 8 \mathrm{~A}$, and $\mathrm{B} 9 \mathrm{~A}$ exceeded the $\mathrm{DOE}$ guideline value of $30 \mathrm{pCi} / \mathrm{g}$. Concentrations of ${ }^{226} \mathrm{Ra}$ ranged from 1.9 to $46 \mathrm{pCi} / \mathrm{g}$ in surface soil and 1.1 to $7.6 \mathrm{pCi} / \mathrm{g}$ in subsurface soil. Eight widely scattered surface soil samples exceeded the DOE guideline value of $5 \mathrm{pCi} / \mathrm{g}$ for ${ }^{226} \mathrm{Ra}$ in surface soil. (Sample B7A with roughly equal amounts of uranium and radium is most likely ore. Sample B10A is considered less than $5 \mathrm{pCi} / \mathrm{g}$ when average background levels of $0.9 \mathrm{pCi} / \mathrm{g}$ are subtracted.) All subsurface samples were below the DOE guideline values of $30 \mathrm{pCi} / \mathrm{g}$ for ${ }^{238} \mathrm{U}$ and $15 \mathrm{pCi} / \mathrm{g}$ for ${ }^{226} \mathrm{Ra}$ in subsurface soil. Concentrations of ${ }^{232} \mathrm{Th}$ ranged from 0.44 to $1.1 \mathrm{pCi} / \mathrm{g}$ in surface and subsurface samples. These concentrations are similar to normal background soil concentrations of ${ }^{232} \mathrm{Th}$ for the Tonawanda area (Table 2) and well below the DOE guideline value of $5 \mathrm{pCi} / \mathrm{g}$ over the first $15 \mathrm{~cm}$ (Table 1 ).

\section{SIGNIFICANCE OF FINDINGS}

Results of this radiological survey indicate that radioactive material probably originating from the Linde plant is located on the Niagara Mohawk right-of-way in the area adjacent to the former Linde plant site east fence, north of the railway spur entrance gate. Surface gamma exposure rates were elevated above typical background levels. Four scattered surface soil samples exceeded DOE guideline values for ${ }^{238} \mathrm{U}$, and 8 of 13 widely scattered surface soil samples exceeded DOE guideline values for ${ }^{226} \mathrm{Ra}$. The radionuclide distribution in these samples was similar to that found in materials resulting from former processing activities at the Linde site. It is recommended that the property be designated for remedial action by $D O E$.

\section{REFERENCES}

1. U. S. Department of Energy, A Background Report for the Formerly Utilized Manhattan Engineer District/Atomic Energy Commission Sites Program, DOE/EV-0097, September 1980.

2. Oak Ridge Natl. Lab., Radiological Survey of the Former Linde Uranium Refinery, Tonawanda, New York, DOE/EV-005/5, UC-70, U.S. Department of Energy, Division of Environmental Control Technology, Formerly Utilized MED/AEC Sites Remedial Action Program, May 1978.

3. R. E. Rodriguez, M. E. Murray, and M. S. Uziel, Results of the Radiological Survey at the Town of Tonawanda Landfill, Tonawanda, New York (TNY001), ORNL/RASA-92/12, Martin Marietta Energy Systems, Inc., Oak Ridge Natl. Lab., October 1992.

4. T. E. Myrick, B. A. Berven, W. D. Cottrell, W. A. Goldsmith, and F. F. Haywood, Procedures Manual for the ORNL Radiological Survey Activities (RASA) Program, ORNL/TM-8600, Martin Marietta Energy Systems, Inc., Oak Ridge Natl. Lab., April 1987.

5. Measurement Applications and Development Group Guidelines, ORNL-6782, Martin Marietta Energy Systems, Inc., Oak Ridge Natl. Lab., January, 1995. 
ORNL_DWG 97-5638

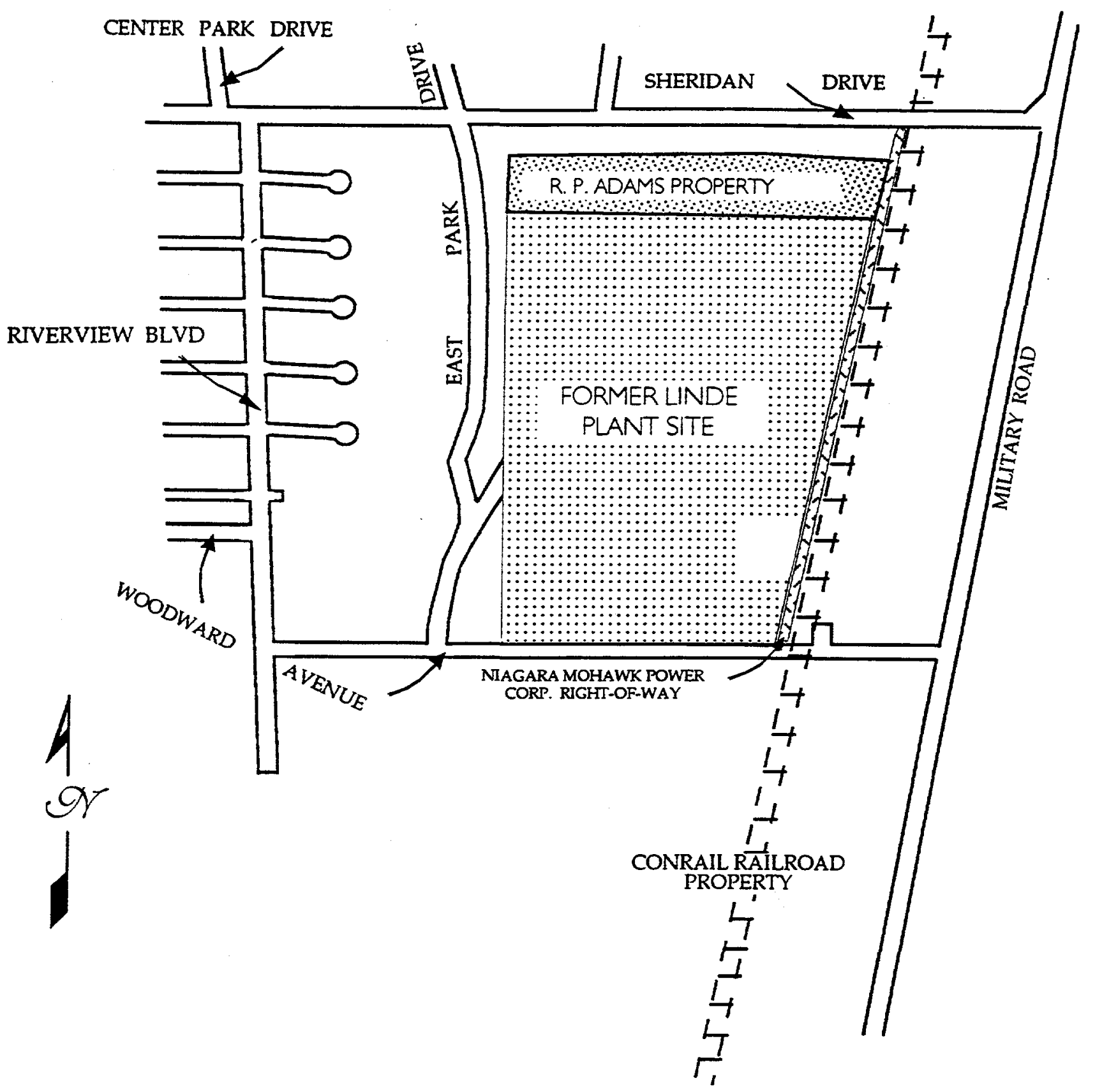

Fig. 1. Diagram showing general location of the Niagara Mohawk Power Corporation right-of-way in relation to the former Linde plant site in Tonawanda, New York. (Not to scale.) 
ORNL-DWG 97-5644

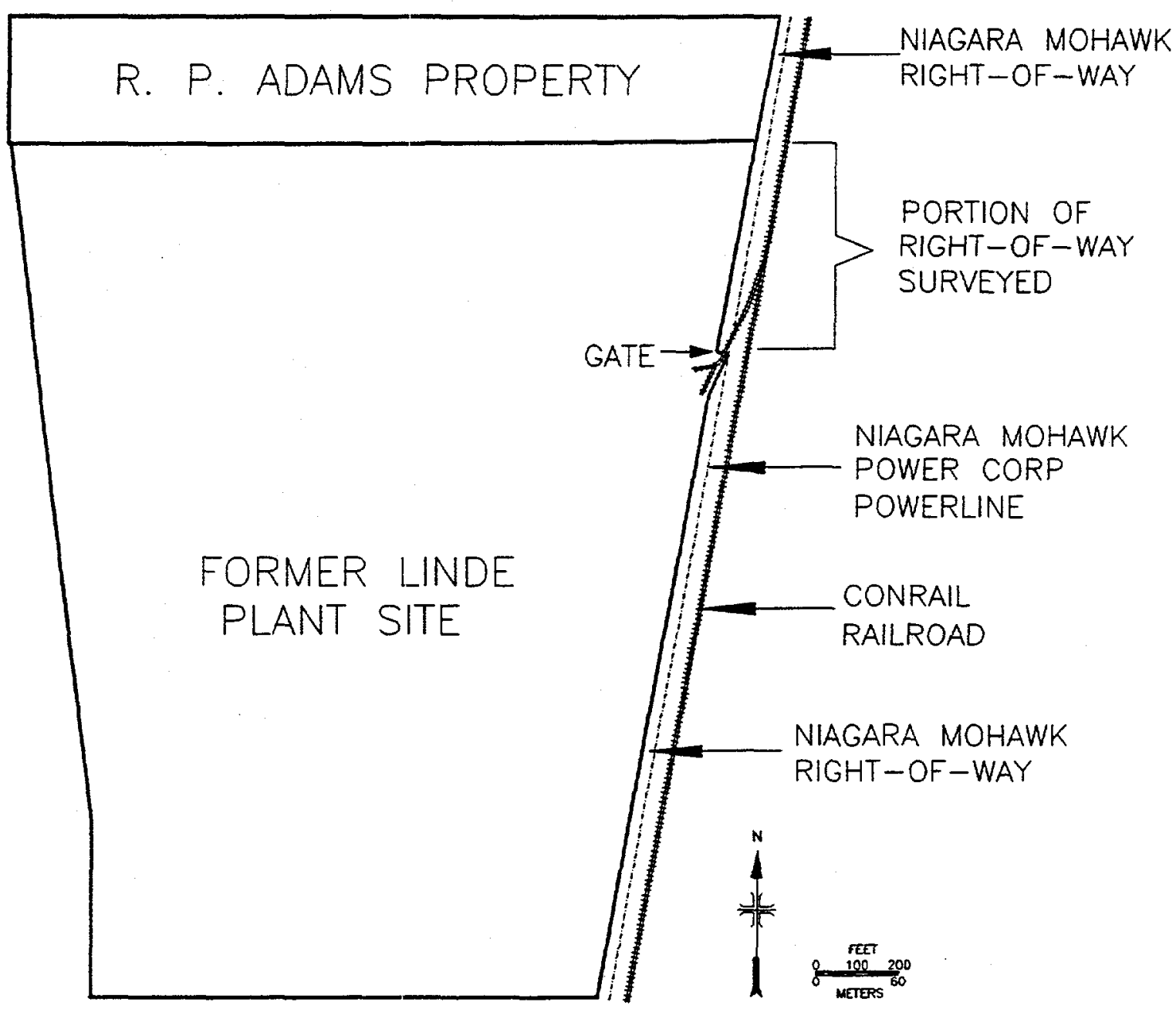

Fig. 2. Diagram delineating portion of Niagara Mohawk right-of-way included in this survey. 
ORNL-DWG $97-5645$

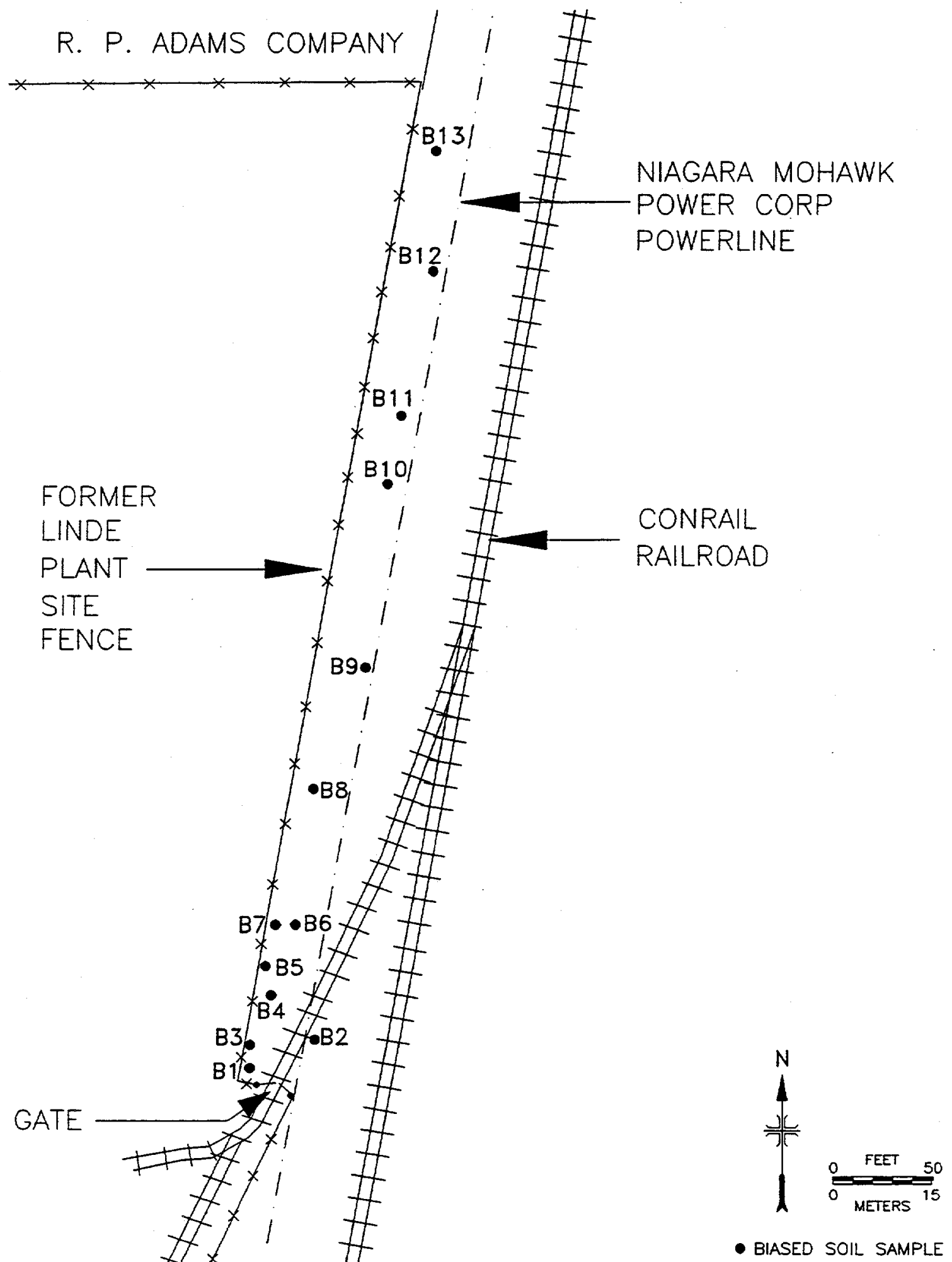

Fig. 3. Diagram showing biased soil sampling locations on the Niagara Mohawk Power Corporation right-of-way, Tonawanda, New York. 


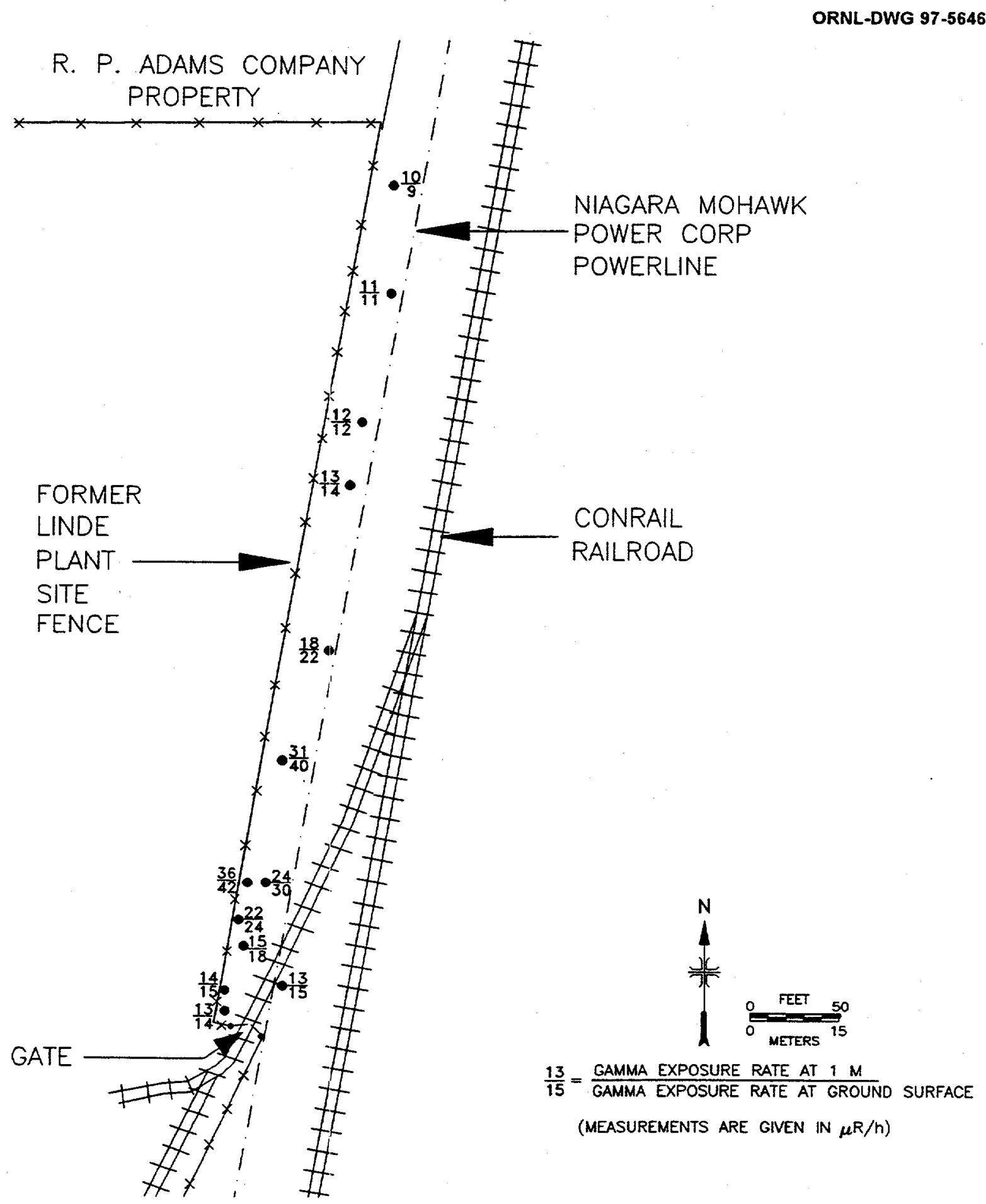

Fig. 4. Diagram showing surface and 1-m gamma exposure rates on the Niagara Mohawk Power Corporation right-of-way. 
Table 1. Applicable guidelines for protection against radiation (Limits for uncontrolled areas)

\begin{tabular}{|c|c|c|}
\hline Mode of exposure & Exposure conditions & Guideline value \\
\hline Gamma radiation & $\begin{array}{l}\text { Indoor gamma radiation level } \\
\text { (above background) }\end{array}$ & $20 \mu \mathrm{R} / h^{a}$ \\
\hline $\begin{array}{l}\text { Radionuclide con- } \\
\text { centrations in soil } \\
\text { (generic) }\end{array}$ & $\begin{array}{l}\text { Maximum permissible con- } \\
\text { centration of the following } \\
\text { radionuclides in soil above } \\
\text { background levels, averaged } \\
\text { over a } 100-\mathrm{m}^{2} \text { area } \\
{ }^{226} \mathrm{Ra} \\
{ }^{232} \mathrm{Th} \\
{ }^{230} \mathrm{Th}\end{array}$ & $\begin{array}{l}5 \mathrm{pCi} / \mathrm{g} \text { averaged over the } \\
\text { first } 15 \mathrm{~cm} \text { of soil below the } \\
\text { surface; } 15 \mathrm{pCi} / \mathrm{g} \text { when } \\
\text { averaged over } 15-\mathrm{cm} \text {-thick } \\
\text { soil layers more than } 15 \mathrm{~cm} \\
\text { below the surface }\end{array}$ \\
\hline Derived concentrations & $\begin{array}{l}\text { Maximum permissible con- } \\
\text { centration of total uranium in } \\
\text { soil above background levels, } \\
\text { averaged over a } 100-\mathrm{m}^{2} \text { area. }\end{array}$ & $60 \mathrm{pCi} / \mathrm{g}^{b}$ \\
\hline $\begin{array}{l}\text { Guideline for non- } \\
\text { homogeneous con- } \\
\text { tamination (used in } \\
\text { addition to the } 100-\mathrm{m}^{2} \\
\text { guideline) }\end{array}$ & $\begin{array}{l}\text { Applicable to locations with } \\
\text { an area } \leq 25 \mathrm{~m}^{2} \text {, with signifi- } \\
\text { cantly elevated concentrations } \\
\text { of radionuclides ("hot spots") }\end{array}$ & $\begin{array}{l}\mathrm{G}_{A}=\mathrm{G}_{i}(100 / \mathrm{A})^{1 / 2}, \\
\text { where } \\
\mathrm{G}_{A}=\text { guideline for "hot } \\
\text { spot" of area (A) } \\
\mathrm{G}_{i}=\text { guideline averaged } \\
\text { over a } 100-\mathrm{m}^{2} \text { area }\end{array}$ \\
\hline
\end{tabular}

The $20 \mu \mathrm{R} / \mathrm{h}$ shall comply with the basic dose limit (100 mrem/year) when an appropriate-use scenario is considered.

${ }^{b}$ Guidelines for uranium are derived on a site-specific basis. A total uranium guideline of $60 \mathrm{pCi} / \mathrm{g}$ will be applied at the Niagara Mohawk right-of-way site. This corresponds to a ${ }^{238} \mathrm{U}$ concentration of $\sim 30 \mathrm{pCi} / \mathrm{g}$.

${ }^{\circ}$ Guidelines specify that every reasonable effort shall be made to identify and to remove any source that has a concentration exceeding 30 times the guideline value, irrespective of area (adapted from Revised Guidelines for Residual Radioactive Material at FUSRAP and Remote SFMP Sites, April 1987).

Sources: Adapted from U.S. Department of Energy, DOE Order 5400.5, April 1990; U.S. Department of Energy, Guidelines for Residual Radioactive Material at Formerly Utilized Sites Remedial Action Program and Remote Surplus Facilities Management Program Sites, Rev. 2, March 1987; and U.S. Department of Energy, Radiological Control Manual, DOE/EH-0256T, Rev. 1, April 1994. 
Table 2. Background radiation levels and concentrations of selected radionuclides in soil near Tonawanda, New York

\begin{tabular}{|c|c|c|}
\hline \multirow{2}{*}{$\begin{array}{c}\text { Type of radiation measurement } \\
\text { or sample }\end{array}$} & \multicolumn{2}{|c|}{$\begin{array}{l}\text { Radiation level or radionuclide } \\
\text { concentration }\end{array}$} \\
\hline & Range & Average \\
\hline $\begin{array}{l}\text { Gamma exposure rate at } \\
\text { ground surface }(\mu \mathrm{R} / \mathrm{h})^{a}\end{array}$ & $8-11$ & 9 \\
\hline \multicolumn{3}{|l|}{$\begin{array}{l}\text { Concentration of radionuclides } \\
\text { in soil }(\mathrm{pCi} / \mathrm{g})^{a}\end{array}$} \\
\hline${ }^{238} \mathrm{U}$ & $0.8-1.1$ & 1.0 \\
\hline${ }^{226} \mathrm{Ra}$ & $0.7-1.1$ & 0.9 \\
\hline${ }^{232} \mathrm{Th}$ & $0.5-0.9$ & 0.8 \\
\hline
\end{tabular}


Table 3. Concentrations of selected radionuclides in soil samples collected from the Niagara Mohawk Power Corporation right-of-way,

Tonawanda, New York

\begin{tabular}{|c|c|c|c|c|c|}
\hline \multirow{2}{*}{$\begin{array}{l}\text { Sample } \\
\mathbb{W}^{a}\end{array}$} & \multirow{2}{*}{$\begin{array}{c}\text { Grid } \\
\text { location }^{a b}\end{array}$} & \multirow{2}{*}{$\begin{array}{l}\text { Depth } \\
(\mathrm{cm})\end{array}$} & \multicolumn{3}{|c|}{ Radionuclide concentration $(\mathrm{pCi} / \mathrm{g})^{c}$} \\
\hline & & & ${ }^{238} \mathrm{U}$ & ${ }^{226} \mathrm{Ra}$ & ${ }^{232} \mathrm{Th}$ \\
\hline \multicolumn{6}{|c|}{ Biased samples ${ }^{d}$} \\
\hline $\begin{array}{l}\text { B1A } \\
\text { B1B }\end{array}$ & $\begin{array}{l}8 \mathrm{~N}, 4 \mathrm{E} \\
8 \mathrm{~N}, 4 \mathrm{E}\end{array}$ & $\begin{array}{r}0-15 \\
15-30\end{array}$ & $\begin{array}{l}11 \pm 4 \\
20 \pm 6\end{array}$ & $\begin{array}{l}6.9 \pm 0.3 \\
5.7 \pm 0.3\end{array}$ & $\begin{array}{l}0.80 \pm 0.1 \\
0.85 \pm 0.2\end{array}$ \\
\hline $\begin{array}{l}\text { B2A } \\
\text { B2B }\end{array}$ & $\begin{array}{l}23 \mathrm{~N}, 27 \mathrm{E} \\
23 \mathrm{~N}, 27 \mathrm{E}\end{array}$ & $\begin{array}{r}0-15 \\
15-30\end{array}$ & $\begin{array}{r}16.0 \pm 5 \\
9.0 \pm 3\end{array}$ & $\begin{array}{l}9.5 \pm 0.4 \\
6.9 \pm 0.3\end{array}$ & $\begin{array}{l}1.1 \pm 0.2 \\
1.1 \pm 0.2\end{array}$ \\
\hline $\begin{array}{l}\text { B3A } \\
\text { B3B }\end{array}$ & $\begin{array}{l}20 \mathrm{~N}, 3 \mathrm{E} \\
20 \mathrm{~N}, 3 \mathrm{E}\end{array}$ & $\begin{array}{r}0-15 \\
15-30\end{array}$ & $\begin{array}{l}11 \pm 1 \\
9.0 \pm 3\end{array}$ & $\begin{array}{l}9.5 \pm 0.4 \\
2.3 \pm 0.1\end{array}$ & $\begin{array}{l}0.72 \pm 0.2 \\
0.86 \pm 0.1\end{array}$ \\
\hline $\begin{array}{l}\text { B4A } \\
\text { B4B }\end{array}$ & $\begin{array}{l}45 \mathrm{~N}, 9 \mathrm{E} \\
45 \mathrm{~N}, 9 \mathrm{E}\end{array}$ & $\begin{array}{r}0-15 \\
15-30\end{array}$ & $\begin{array}{l}19 \pm 6 \\
10 \pm 1\end{array}$ & $\begin{array}{l}8.7 \pm 0.4 \\
7.6 \pm 0.4\end{array}$ & $\begin{array}{l}0.44 \pm 0.1 \\
0.80 \pm 0.2\end{array}$ \\
\hline $\begin{array}{l}\text { B5A } \\
\text { B5B }\end{array}$ & $\begin{array}{l}60 N, 3 E \\
60 N, 3 E\end{array}$ & $\begin{array}{r}0-15 \\
15-30\end{array}$ & $\begin{array}{l}39 \pm 5 \\
15 \pm 1\end{array}$ & $\begin{array}{c}15 \pm 0.6 \\
4.7 \pm 0.2\end{array}$ & $\begin{array}{l}0.73 \pm 0.1 \\
0.79 \pm 0.1\end{array}$ \\
\hline $\begin{array}{l}\text { B6A } \\
\text { B6B }\end{array}$ & $\begin{array}{l}81 \mathrm{~N}, 15 \mathrm{E} \\
81 \mathrm{~N}, 15 \mathrm{E}\end{array}$ & $\begin{array}{r}0-15 \\
15-30\end{array}$ & $\begin{array}{c}48 \pm 5 \\
9.5 \pm 3\end{array}$ & $\begin{aligned} 28 & \pm 1 \\
5.2 & \pm 0.3\end{aligned}$ & $\begin{array}{l}0.95 \pm 0.2 \\
0.94 \pm 0.1\end{array}$ \\
\hline $\begin{array}{l}\text { B7A } \\
\text { B7B }\end{array}$ & $\begin{array}{l}81 N, 5 E \\
81 N, 5 E\end{array}$ & $\begin{array}{r}0-15 \\
15-30\end{array}$ & $\begin{array}{l}14 \pm 1 \\
23 \pm 1\end{array}$ & $\begin{array}{c}15 \pm 0.7 \\
4.4 \pm 0.3\end{array}$ & $\begin{array}{l}1.0 \pm 0.2 \\
1.2 \pm 0.2\end{array}$ \\
\hline $\begin{array}{l}\text { B8A } \\
\text { B8B }\end{array}$ & $\begin{array}{l}153 \mathrm{~N}, 12 \mathrm{E} \\
153 \mathrm{~N}, 12 \mathrm{E}\end{array}$ & $\begin{array}{r}0-15 \\
15-30\end{array}$ & $\begin{array}{c}100 \pm 10 \\
9.3 \pm 1\end{array}$ & $\begin{aligned} 46 & \pm 2 \\
4.9 & \pm 0.3\end{aligned}$ & $\begin{array}{l}1.1 \pm 0.4 \\
1.0 \pm 0.2\end{array}$ \\
\hline $\begin{array}{l}\text { B9A } \\
\text { B9B }\end{array}$ & $\begin{array}{l}217 \mathrm{~N}, 25 \mathrm{E} \\
217 \mathrm{~N}, 25 \mathrm{E}\end{array}$ & $\begin{array}{r}0-15 \\
15-30\end{array}$ & $\begin{array}{l}36 \pm 3 \\
21 \pm 1\end{array}$ & $\begin{array}{c}16 \pm 0.7 \\
5.7 \pm 0.3\end{array}$ & $\begin{array}{l}0.85 \pm 0.2 \\
1.0 \pm 0.2\end{array}$ \\
\hline $\begin{array}{l}\text { B10A } \\
\text { B10B }\end{array}$ & $\begin{array}{l}312 \mathrm{~N}, 20 \mathrm{E} \\
312 \mathrm{~N}, 20 \mathrm{E}\end{array}$ & $\begin{array}{r}0-15 \\
15-30\end{array}$ & $\begin{array}{l}15 \pm 1 \\
3.9 \pm 0.5\end{array}$ & $\begin{array}{l}5.2 \pm 0.3 \\
1.5 \pm 0.2\end{array}$ & $\begin{array}{l}0.87 \pm 0.2 \\
1.1 \pm 0.2\end{array}$ \\
\hline $\begin{array}{l}\text { B11A } \\
\text { B11B }\end{array}$ & $\begin{array}{l}347 \mathrm{~N}, 20 \mathrm{E} \\
347 \mathrm{~N}, 20 \mathrm{E}\end{array}$ & $\begin{array}{r}0-15 \\
15-30\end{array}$ & $\begin{array}{l}9.2 \pm 1 \\
3.4 \pm 2\end{array}$ & $\begin{array}{l}4.1 \neq 0.2 \\
1.8 \pm 0.1\end{array}$ & $\begin{array}{l}0.74 \pm 0.2 \\
0.90 \pm 0.1\end{array}$ \\
\hline $\begin{array}{l}\mathrm{B} 12 \mathrm{~A} \\
\mathrm{~B} 12 \mathrm{~B}\end{array}$ & $\begin{array}{l}425 \mathrm{~N}, 25 \mathrm{E} \\
425 \mathrm{~N}, 25 \mathrm{E}\end{array}$ & $\begin{array}{r}0-15 \\
15-30\end{array}$ & $\begin{array}{l}9.9 \pm 0.9 \\
2.5 \pm 1\end{array}$ & $\begin{array}{l}4.2 \pm 0.2 \\
1.1 \pm 0.08\end{array}$ & $\begin{array}{l}0.72 \pm 0.1 \\
0.45 \pm 0.09\end{array}$ \\
\hline $\begin{array}{l}\text { B13A } \\
\text { B13B }\end{array}$ & $\begin{array}{l}487 \mathrm{~N}, 15 \mathrm{E} \\
487 \mathrm{~N}, 15 \mathrm{E}\end{array}$ & $\begin{array}{r}0-15 \\
15-30 \\
\end{array}$ & $\begin{array}{l}3.6 \pm 2 \\
4.2 \pm 0.6 \\
\end{array}$ & $\begin{array}{l}1.9 \pm 0.1 \\
1.8 \pm 0.1 \\
\end{array}$ & $\begin{array}{l}1.1 \pm 0.1 \\
1.0 \pm 0.2 \\
\end{array}$ \\
\hline
\end{tabular}

aSample locations are shown on Fig. 3.

Sample location determined by number of feet north of mid-point of gate (Fig. 3) and number of feet east of fence

${ }^{c}$ Indicated counting error is at the $95 \%$ confidence level $( \pm 2 \sigma)$.

${ }^{d}$ Biased samples were collected at accessible locations to give a representation of rad levels at the site. Systematic sampling could not be conducted. 